\title{
Urdimento
}

Revista de Estudos em Artes Cênicas E-ISSN: 2358.6958

\section{Zintkala Woihanbla (Sonhos de Pássaros): deriva e outras performances decoloniais para sobreviver a e abolir a prisão}

Tria Blu Wakpa

George Blue Bird

\section{Para citar este artigo:}

BLU WAKPA, Tria; BLUE BIRD, George. Zintkala Woihanbla (Sonhos de Pássaros): deriva e outras performances decoloniais para sobreviver a e abolir a prisão. Urdimento, Florianópolis, v. 3, n. 39, nov./dez. 2020. 
Zintkala Woihanbla (Sonhos de Pássaros): deriva e outras performances decoloniais para sobreviver a e abolir a prisão ${ }^{1}$

Tria Blu Wakpa²

George Blue Bird ${ }^{3}$

\section{Resumo}

Pesquisas muitas vezes negligenciaram como os nativos americanos, que estão desproporcionalmente presos, desenvolveram táticas para lidar com a prisão a longo prazo. Com base nas correspondências e conversas entre os autores, este ensaio apresenta performances decoloniais praticadas por George Blue Bird, em condições de violência carcerária, para sobreviver a e abolir a prisão. Estas táticas de enfrentamento são: 1. alimentar conexões com mais-que-humanos; 2. deriva, termo adotado por Blue Bird para imaginar, viajar e habitar outros reinos; e 3. ativar a liberdade e o futuro. Em última análise, concentramo-nos no que estas táticas e epistemologias Lakota oferecem ao movimento de abolição da prisão.

Palavras-chave: Nativo americano. Colonialismo. Prisão. Performance. Abolição. Antropocentrismo. Enfrentamento.

Zintkala Woihanbla (Bird Dreams): Drifting and Other Decolonial Performances for Survival and Prison Abolition

\section{Abstract}

Scholarship has often overlooked how Native Americans, who are disproportionately imprisoned, have developed tactics to cope with long-term imprisonment. Drawing on the authors' correspondences and conversations, this essay features decolonial performances for survival and prison abolition, which George Blue Bird (Oglala Lakota) has enacted within conditions of carceral violence. These interlocking tactics are 1. nurturing connections with more-than-humans; 2. "drifting," Blue Bird's term for imagining, traveling to, and inhabiting other realms; and 3. activating freedom and futurities. Ultimately, we focus on what these tactics and Lakota epistemologies offer the prison abolition movement.

Keywords: Native American. Settler Colonialism. Prison. Performance. Abolition. Anthropocentrism. Coping.

${ }^{1}$ Tradução do inglês realizada por Caroline Vetori de Souza, Helena Maia Antoniassi e Laís Jacques Marques. Revisão da tradução de Vicente Concilio.

2 Dra. Tria Blu Wakpa é professora do Departamento de Artes e Culturas Mundiais / Dança da UCLA ( Universidade da Califórnia em Los Angeles ) desde 2018. Sua pesquisa e ensino combinam metodologias comunitárias, indígenas e feministas com teorias críticas raciais para examinar as políticas e práticas da dança e outras práticas em instituições educacionais e carcerárias para povos indígenas. triabluwakpa@g.ucla.edu

${ }^{3}$ Um ancião Oglala Lakota, George Blue Bird, é escritor, artista e ativista. Atualmente, ele atua como presidente do Conselho de Tribos dos Nativos Americanos na Penitenciária do Estado de Dakota do Sul, onde está preso há trinta e seis anos sem a possibilidade de liberdade condicional. 
Zintkala Woihanbla (Sueños de Pájaro): la deriva y otras actuaciones descoloniales para sobrevivir y abolir la prisión

\section{Resumen:}

La investigación ha pasado por alto a menudo cómo los nativos americanos, que están desproporcionadamente encarcelados, han desarrollado tácticas para hacer frente a la prisión a largo plazo. Basado en la correspondencia y conversaciones entre los autores, este ensayo presenta las actuaciones descoloniales de George Blue Bird, bajo condiciones de violencia carcelaria, para sobrevivir y abolir la prisión. Estas tácticas de afrontamiento son: 1. alimentar las conexiones con más-que-loshumanos; 2. La deriva, un término de Pájaro Azul adoptado para imaginar, viajar y habitar otros reinos; y 3. activar la libertad y el futuro. En última instancia, nos centramos en lo que estas tácticas y epistemologías Lakota ofrecen al movimiento de abolición de las prisiones.

Palabras clave: Nativo Americano. El colonialismo. Prisión. La actuación. Abolición. Antropocentrismo. Confrontación. 
Tudo o que sabemos foi tomado da gente por forças de roubo e destruição que se destinavam a nos destruir.

(George Blue Bird, Oglala - Lakota, 1 jun. 2020)

Palavras são tudo o que eu sei para alcançar o mundo lá fora. Elas me confortam. Envie-me alguns cavalos depois que eles beberem muita água das montanhas.

(Blue Bird, 21 jun. 2020)

Eu acredito que podemos fazer qualquer coisa. A liberdade tem que ser atraída para longe das correntes e limites que não nos permitem respirar. Quando estamos em defesa um do outro (...) estamos protegendo nosso direito de ser criativos em todas as situações.

(Blue Bird, 12 jan. 2020)

Muitas vezes penso em ser um jornalista indígena e cobrir histórias sobre nosso povo nas penitenciárias de todas as terras. Eu não me importaria.

(Blue Bird, 4 jan. 2020)

George Blue Bird ${ }^{4}$ - um ancião Oglala Lakota - é um escritor, artista e ativista. Atualmente, ele atua como presidente do Conselho de Tribos dos Nativos Americanos, na Penitenciária do Estado da Dakota do Sul, onde está preso há trinta e seis anos sem possibilidade de liberdade condicional. Embora estudos tenham delineado como algumas pessoas cumprindo pena de prisão perpétua

${ }^{4}$ George Blue Bird é pai, avô, artista autodidata, dançarino tradicional, cerimonialista, ativista, cantor, compositor, escritor e locutor de powwow. Tasunke Witko (Cavalo Louco) e Tecumseh são seus mentores, cuja liderança e habilidades de guerreiro o impressionam. As terras do Tratado de Fort Laramie de 1868 são o seu foco. Estas terras foram roubadas de seus ancestrais por soldados ordenados a começar a matá-los e destruí-los. Ele fala, escreve, interpreta e protege a língua Lakota. Hante Wakan Waapiya Tipi (Portal Sagrado do Cedro Curativo) é uma proposta que ele gostaria de ver materializada como o maior programa de reinserção de egressos do sistema penal, projetado exclusivamente para os infratores tribais. Suas maiores referências de escrita são Paul Gregg Jr. e Derrick Jensen. Estes homens sabem a verdade sobre a vida. A Ponte Golden Gate, em São Francisco, é um lugar que ele gostaria de atravessar pelo menos duas vezes para sentir a exuberância natural da liberdade. As vozes de lá enviam mensagens para o oceano profundo, e as baleias sempre as respondem com canções sobre unidade e resistência. Ele apoia as pessoas indígenas e cavaleiros que se lembram de todos os nativos que foram enforcados, massacrados, assassinados, torturados e forçados a marchar rumo à morte. O sistema prisional em Dakota do Sul não permite que o tabaco seja usado em suas cerimônias, então ele pede aos religiosos externos para colocar muito dele nas terras, como uma oferenda. 
desenvolveram táticas que thes permitem lidar com a prisão prolongada, os nativos americanos ${ }^{5}$, que são desproporcionalmente presos, têm sido frequentemente negligenciados (Crew; Hulley; Wright; 2017; Flanagan, 1981; Zamble, 1992). Este ensaio, escrito em colaboração com Blue Bird e baseado nas múltiplas correspondências e conversas telefônicas que tivemos desde 2018, apresenta três performances decoloniais ${ }^{6}$ para sobreviver a e abolir a prisão que preservam e ativam as epistemologias Lakota, que foram realizadas por Blue Bird dentro da violência inescapável do sistema carcerário. Essas táticas entrelaçadas incluem 1. alimentar conexões com os mais-que-humanos7; 2. "deriva", termo de Blue Bird para imaginar, viajar e habitar outros territórios; 3. e ativar a liberdade e imaginar o futuro por meio da organização coletiva, do trabalho árduo e da persistência, de oferendas e de práticas artísticas. As valiosas contribuições que Blue Bird compartilhou com a sociedade, tanto dentro quanto fora dos muros da prisão, não podem absolver a devastação da lógica carcerária. Em última análise, concentramo-nos no que as táticas de Blue Bird e as epistemologias Lakota, especialmente as relações humanas e mais-que-humanas, oferecem ao movimento de abolição da prisão. As interdependências entre humanos e maisque-humanos fundamentam não apenas as epistemologias Lakota, mas também a abolição da prisão. Como a aclamada abolicionista penal e acadêmica Ruth Wilson Gilmore articulou: "A abolição é total; trata-se da totalidade das relações humanas e ambientais." (Kushner, 2019).

No entanto, a maior parte da literatura sobre táticas de enfrentamento de

\footnotetext{
${ }^{5}$ Nota de tradução: optou-se por adotar a tradução literal dos termos native american (nativo americano) e/ou native indigenous (nativo indígena) a fim de preservar a forma com que os estadunidenses costumam se referir às populações indígenas.

${ }^{6}$ Nota de tradução: optou-se pelo uso do termo decolonial por considerar que a autora se refere aos processos de desvencilhamento das amarras coloniais, propondo uma virada epistemológica que transcende os ditames da colonialidade.

${ }^{7}$ Neste ensaio, definimos mais-que-humanos como ar, terra, água e animais não humanos.

${ }^{8}$ Nota de tradução: dentro do contexto das Ciências Sociais, nos Estados Unidos, é comum se utilizar do tipo de citação parenthetical quando pretende-se exprimir uma síntese de um conceito desenvolvido na publicação referenciada. Para tanto, coloca-se a síntese entre aspas e, entre parênteses e logo após a síntese, a autoria e o ano da publicação. O nome parenthetical refere-se, então, à necessidade de incluir nome e ano entre parênteses e, como não refere-se a um excerto da obra referenciada, não possui paginação.
} 
pessoas que são condenadas à prisão perpétua não parte de uma perspectiva abolicionista (Crew; Hulley; Wright, 2017; Flanagan, 1981; Zamble, 1992). Alguns destes estudos também ignoraram as injustiças inerentes à sociedade estadunidense e como estas estão indissociavelmente ligadas ao sistema jurídico do Estado colonizador (Johnson; Dovrzanska, 2005; Flanagan, 1981; Zamble, 1992). Contudo, como enfatiza Luana Ross, cujo trabalho é fundamental para os estudos prisionais dos nativos americanos:

Qualquer explicação da criminalidade cometida pelos nativos que veja o comportamento individual como significativo ignora as origens sociais e históricas desse comportamento. Uma análise completa dessa criminalidade deve incluir todo o contexto do comportamento criminoso - isto é, a vitimização e a criminalização dos direitos dos nativos e nativas estadunidenses pelo governo dos Estados Unidos (Ross, 1998, p.12).

De fato, na citação que abre este artigo, o próprio Blue Bird destaca os impactos duradouros do colonialismo, que é evidenciado por suas décadas de prisão em terras Lakota ocupadas. (Blue Bird, 1 jun. 2020).

Quando deixam de levar em conta as estruturas sociais, os estudiosos podem inadvertidamente criminalizar e deturpar as pessoas que estão/foram encarceradas. Robert Johnson e Ania Dovrzanska referem-se às pessoas que estão/foram presas como reclusas e as táticas que empregam para sobreviver dentro do confinamento como "enfrentamento maduro" (Johnson e Dovrzanska, 2005, p.8). Todavia, sua estrutura de "enfrentamento maduro" ignora como a colonização dos EUA "violou os direitos de outros" por mais de 500 anos e como a "decepção [e a] violência" (Johnson; Dovrzanska, 2005, p.8) sancionadas pelo Estado têm desproporcionalmente visado povos nativos e negros. Ashley Lucas adverte: "Nunca devemos esquecer que nossas noções de liberdade são construídas sobre as costas daqueles que não são livres” (Lucas, 2020). Johnson e Dovranska também confundem "maturidade" (Johnson; Dovrzanska, 2005, p.8) com a capacidade de se conformar - pelo menos externamente - a um sistema injusto e, portanto, implica que algumas formas de resistência justa sejam imaturas. Infelizmente, Emily Brault - cujo trabalho se concentra nos povos nativos 
e analisa a colonização - também usa o conceito de enfrentamento maduro, sem considerar que interpretar os nativos como infantis e inferiores foi fundamental para o projeto colonial (Brault, 2005). Outra estratégia do colonialismo é a imposição de hierarquias de conhecimento, e a conclusão deste ensaio critica essas hierarquias desafiando as construções eurocêntricas ao relacioná-las com "maturidade".

Embora a escolarização atual enfatize as formas sancionadas, os programas educacionais das prisões podem ser importantes para pessoas que estão/foram encarceradas (Brault, 2005; Hanley; Marchetti, 2020; Grant, 2008), e podem dar algum sentido positivo aos centros de detenção e diminuir a violência que eles infligem. Essas atividades podem ser muito significativas para as pessoas que estão presas - e talvez em particular, para aquelas com sentenças de longa duração. No entanto, a literatura que defende a reforma prisional pode fortalecer e solidificar o sistema carcerário (Davis, 2015). Grande parte deste trabalho aceita a prisão como uma solução "necessária, natural e inevitável" para a violação das leis do Estado colonizador (Gilmore; Estes; Hale; Sepúlveda, 2020). Mesmo os estudiosos que concluem que a prisão perpétua, a qual eles se referem como "a morte por encarceramento é tão definitiva, tão dolorosa e tão digna do escrutínio cuidadoso a que submetemos as sentenças de morte" (Johnson; McGunigallSmith, 2008, p.344), ainda não condenam completamente esta prática.

Por outro lado, Gilmore imagina um mundo que não inflige punição corporal e crueldade (Kushner, 2019). Ela propõe uma estrutura abolicionista da prisão que é "verde" e "vermelha" - isto é, ambientalmente justa e comunista?, respectivamente - e "internacional" (Gilmore; Estes; Hale; Sepulveda, 2020), algo que as narrativas do Blue Bird também evidenciam. Realizando leituras atentas de conversas e correspondências com Blue Bird, este artigo expande a estrutura de Gilmore ao conceituar "vermelho" como valores e práticas nativas - que enfatizam a reciprocidade e doações - e ao explicitar que a abolição também requer um "sonho", isto é, imaginar e encenar possibilidades que desafiam o "senso comum" 
sobre a prisão, em formas nas quais ela é confundida com "justiça". Ao tecer esse argumento, este ensaio também apresenta a epistemologia Lakota e outras epistemologias nativas nas quais os sonhos são conceituados como formas de conhecimento válidas e poderosas que podem inspirar e realizar objetivos. (Posthumus, 2018) $)^{10}$.

A atenção acadêmica às propostas de atividades sancionadas pela prisão costuma elogiar as intervenções de pessoas de fora da prisão, enquanto eclipsa as valiosas contribuições de pessoas que estão/estiveram presas (Hanley; Marchetti, 2020). Em outras palavras, o foco nas atividades sancionadas pela prisão pode obscurecer as maneiras como os "intelectuais radicais presos" (Rodriguez, 2006, p. 3) têm sido, em alguns casos, centrais para criar e consolidar movimentos de mudança. Na Penitenciária do Estado da Dakota do Sul, homens Lakota que estão/foram presos coletivamente organizaram-se, em 1976, para formar o Conselho de Tribos dos Nativos Americanos, e ter encontros e cerimônias culturalmente relevantes na prisão (Blue Bird, 30 jul. 2020). Focalizar as contribuições de pessoas que estão/estiveram encarceradas pode revelar formas alternativas de conhecimento e preservar existências e críticas que desestabilizam o Estado colonizador. Como articulou o abolicionista e estudioso da prisão Dylan Rodriguez, a circulação de histórias de pessoas que estão/foram presas oferece possibilidades de crescimento e fortalecimento da justiça social e os movimentos de abolição de uma forma que as estatísticas não são capazes. (Critical Resistance, 2017).

Este ensaio em co-autoria oferece uma contribuição à literatura atual sobre os mecanismos de enfrentamento de pessoas que estão/foram presas, destacando as limitações e violências inescapáveis do ambiente carcerário, ao mesmo tempo que evidencia a agência individual e a criatividade de Blue Bird, articulando a forma como as suas performances podem informar o movimento de abolição prisional contemporâneo e conduzir pesquisas com uma pessoa que está atualmente encarcerada, ao invés de enxergá-la como um objeto de pesquisa.

10 Notavelmente, porque os discursos eurocêntricos frequentemente conceituam as prisões como "senso comum" e os sonhos como utópicos, os abolicionistas têm por vezes procurado distanciar seu trabalho de sonhar. (Gilmore; Crispino, 2020). 
Em conversa com a descrição de Gilmore de que o abolicionismo é "a vida em ensaio, não uma repetição de regras e erros" (Gilmore; Estes; Hale; Sepulveda, 2020), e a discussão do estudioso Tongva, Charles Sepulveda (2020), sobre decolonização e movimentos abolicionistas como processos criativos contínuos, Blue Bird e eu concebemos amplamente o que constitui uma performance. Definimos decolonial centralizando as epistemologias Lakota, contrariando as lógicas eurocêntricas e desafiando as fronteiras do confinamento. Como explica Sepulveda, os objetivos da decolonização e da abolição estão "intimamente ligados um ao outro"; ambos implicam "a luta contínua pela liberdade" (Gilmore; Estes; Hale; Sepulveda, 2020). Embora, em alguns casos, seja vital não confundir sentimentos de liberdade com a real abolição da prisão, os especialistas nativos também encorajam as pessoas a não excluir a possibilidade de alcançar a emancipação dentro dos limites do sistema atual - não importa o quão fugaz esse momento possa ser. Leanne Simpson teoriza, "podemos criar uma ilha literal de amor decolonial - uma bolha por alguns minutos pelo menos, aprendemos como é escapar das cadeias do colonialismo" (Simpson; Winder, 2014). Essas "ilhas de amor decolonial" (Simpson; Winder, 2014) - ou o que chamamos de performances decoloniais - podem combater "as forças de roubo e destruição (...) destinadas a destruir" (Blue Bird,1 jun. 2020). Os povos indígenas, sustentando e reforçando a sua determinação de sobreviver.

Este ensaio também apresenta metodologias de pesquisa nativas, decoloniais, que enfatizam "respeito, reciprocidade e relacionalidade" (Wilson, 2008, p. 99). Ao longo do processo de redação deste artigo, Blue Bird e eu nos comunicamos por telefone e pelo sistema de mensagens online contratado pela Penitenciária do Estado da Dakota do Sul. No entanto, este ensaio também se confronta com os fracassos da "colaboração" dos autores e os limites da "reciprocidade" (Rodriguez, 2006, p. 37-38), uma vez que Blue Bird está atualmente preso. Por exemplo, os métodos de pesquisa nativa frequentemente enfatizam a importância de informar os parceiros da comunidade (Smith, 2013); no entanto, o encarceramento de Blue Bird levanta questões sobre como navegar compartilhando os resultados de pesquisas no contexto carcerário. Atualmente, 
não sei se a Penitenciária do Estado da Dakota do Sul me permitirá partilhar este ensaio impresso com Blue Bird, e se é sensato dar destaque ao trabalho que estamos fazendo para os funcionários prisionais - que controlam se Blue Bird e eu podemos nos comunicar -, especialmente porque Blue Bird e eu temos planos para continuar a trabalhar juntos. Eu também acho que as metodologias de pesquisa nativa e as regras e regulamentos carcerários estão frequentemente em desacordo. Considerando que as metodologias de pesquisa nativa enfatizam a construção de relacionamentos fortes, o Manual do Voluntário da Penitenciária do Estado da Dakota do Sul tem várias regras que destacam como os voluntários devem manter limites precisos com as pessoas que estão encarceradas (Kaemingk, 2018). A certa altura, durante a realização de pesquisas na Penitenciária do Estado da Dakota do Sul, um voluntário e oficial da prisão me incentivou a obter o status de voluntária, para que eu pudesse entrar e sair da instituição sem que outra pessoa me acompanhasse. No entanto, quando comecei a ler o Manual, percebi que me tornar uma voluntária exigiria que eu não aceitasse ligações de Blue Bird e que eu obtivesse a aprovação do diretor antes de publicar qualquer escrito relacionado à prisão (Kaemingk, 2018). Parece-me que, como pesquisadora - nem voluntária, nem funcionária -, estou em uma posição liminar e, portanto, sempre correndo o risco de ser impedida de entrar na prisão e de me comunicar com Blue Bird, que se tornou meu amigo e mentor.

Embora muitas vezes eu não possa colocar em prática a reciprocidade no meu trabalho com Blue Bird, como faria com os meus parceiros de comunidade que não estão encarcerados, faço o que posso: compartilhar anedotas com ele, dizer-lhe o quanto considero o conhecimento que ele partilha comigo e o quanto aprecio suas palavras poderosas e comoventes, pedindo no final de quase todas as conversas que temos para tomar cuidado, e lembrando-o diariamente nas minhas orações. Recentemente, eu estava ouvindo um podcast apresentado por Kim Smith, uma "organizadora comunitária, cientista social, ativista, protetora da água, empresária, escritora [e] jardineira” dos povos Diné (Wilbur; Keene, 2020). Articulando uma abordagem nativa para a colheita de plantas, ela perguntou: "o que você precisa fazer para que, quando você colete, haja reabastecimento para 
os outros e para a próxima temporada?” (Wilbur; Keene, 2020). Tenho considerado a pergunta de smith no contexto dos métodos de pesquisa nativas: o que precisamos fazer para que, quando coletamos junto a nossos parceiros de comunidade, eles possam se reabastecer para os outros e para a próxima temporada? De que formas podemos reabastecer as parcerias comunitárias, mesmo quando estão encarceradas? O que nossas relações com os mais-quehumanos podem nos ensinar sobre a abolição das prisões?

\section{Cultivando conexões com mais-que-humanos}

Blue Bird opõe-se aos regulamentos carcerários que separam os humanos de mais-que-humanos ao se engajar em performances decoloniais que nutrem conexões com seres não humanos dentro e fora do ambiente da prisão. Essas performances representam as epistemologias Lakota, que entendem humanos e mais-que-humanos como interdependentes (White Hat, 1999). A prisão interrompe as interconexões humanas e mais-que-humanas de várias maneiras. Apesar de raramente estar ao ar livre à noite e ter acesso limitado para ver a lua cheia da janela de sua cela, Blue Bird continuou a valorizar sua presença a cada mês durante seus 36 anos de confinamento. Blue Bird compartilhou comigo o significado da lua para o povo Lakota.

\footnotetext{
Nossas tribos Lakota usam a lua como um lembrete de tempo e lugar. Temos um nome para cada mês. A lua cheia é um ser importante. É celebrada com amor familiar e pura honra. Muitos sairão e farão uma fogueira. Fevereiro, em outros termos, é uma energia dos corações em todo o mundo. 9 de fevereiro é nossa próxima lua cheia e espero que isso the traga muitos minutos de belas paisagens, enquanto você dirige seu veículo. (Blue Bird, 5 fev. 2020).
}

Embora a prisão de Blue Bird o impeça de ver a lua cheia, como uma pessoa Lakota, ele ainda observa sua chegada, o que the permite notar "tempo e lugar" (Blue Bird, 5 fev. 2020). Descrever a lua cheia como um ser importante implica formas Lakota de saber, que, ao contrário das epistemologias eurocêntricas, não hierarquizam os humanos sobre os mais-que-humanos (Blue 
Bird, 5 fev. 2020). Blue Bird valoriza as ações que muitos Lakota farão para celebrar a lua cheia e o tempo sazonal (Blue Bird,5 fev. 2020). Sua mensagem me incentiva, como leitora, a apreciar a lua cheia observando-a, o que ele não pode fazer. Desta forma, Blue Bird ensina pessoas não-Lakota além dos muros da prisão a compreender e representar epistemologias Lakota.

Algumas das recentes reformulações prisionais interromperam ainda mais as interconexões humanas e mais-que-humanas. Blue Bird declarou em uma mensagem:

Estou preparando meu espírito criativo para a lua cheia que dará energia e vida nova a todas as coisas no dia 10, mais uma vez. Todas as minhas chances de vê-la foram tiradas pelas novas janelas que foram colocadas. Não podemos ver nada. Se eu sair na manhã seguinte à sua chegada, talvez eu possa vê-la. Não ver a lua cheia me desequilibra. (Blue Bird, 5 jan. 2020).

As palavras do Blue Bird evidenciam que ele se prepara - e em particular, seu espírito criativo - para a lua cheia antes de sua chegada. Embora o Blue Bird antecipe a lua cheia, que "dará energia e vida nova a todas as coisas" (Blue Bird, 5 jan. 2020), as reformas na prisão impossibilitaram que ele a veja, e isso o desequilibra. Independentemente de sua origem, muitas pessoas gostam de ver o céu, a lua e animais mais-que-humanos. No entanto, como as conexões humanas e mais-que-humanas são epistemologias nativas fundamentais, é possível que essas restrições tenham um impacto desproporcional e prejudicial sobre o bemestar/sobrevivência indígena em contextos carcerários (White Hat, 1999).

Por outro lado, uma obra recente na prisão forneceu temporariamente oportunidades preciosas para os homens que estão encarcerados poderem sair à noite para assistir e se conectar com mais-que-humanos. Blue Bird escreveu para mim:

Ontem vi alguns guindastes voando alto e gansos da neve fazendo sua jornada de volta para seus acampamentos ao sul para o inverno. Espero ver mais deles hoje. Minha conexão com os pássaros e todos os animais me guia para tempos melhores. Os cães são meus favoritos. Saímos para recreação noturna por causa da obra e é realmente uma honra ver e me comunicar com a noite e as criaturas. Há uma estrela no céu quando olho em direção ao México e gosto de tudo isso. Sexta-feira será nosso último dia. Espero que possamos passar mais noites fora. Esta noite a lua cheia 
surgirá sobre os oceanos e montanhas do leste e sua essência colorida dará a cada ser vivo um novo propósito para continuar sendo forte... Será que os pássaros sonham? Honre-se e dê um longo passeio. Haho! Haho! (Blue Bird,1 out. 2020).

Esta passagem ilustra a observação perspicaz de Blue Bird dos mais-quehumanos e sua consideração sobre os guindastes, das geografias além da penitenciária e das conexões vitais com os mais-que-humanos, que em alguns casos dão a "cada ser um novo propósito para continuar sendo forte" (Blue Bird, 1 out. 2020). Blue Bird sente "esperança" e "honra" com a possibilidade de visualização e "comunicação" com os mais-que-humanos, que o guiam para tempos melhores, provavelmente anteriores ao de seu aprisionamento (Blue Bird, 1 out. 2020). Ele menciona que o cão é seu animal mais-que-humano "favorito" e já me disse que gosta de treinar cães na prisão (Blue Bird, 1 out. 2020). Em setembro de 2004 e em colaboração com a Sioux Falls Area Humane Society, a Penitenciária do Estado da Dakota do Sul iniciou o programa Filhotes em liberdade condicional para que pessoas que estão cumprindo pena em segurança mínima possam "ajudar a ensinar comandos básicos de obediência para cães abrigados" (Departamento de Correções, Dakota do Sul, 2020). Este programa evidencia que a prisão implementou um programa que facilita as interconexões e reciprocidades humanas e mais-que-humanas. Tal como a obra na prisão, o treino de um cão para o programa Filhotes em liberdade condicional é temporário, e o mais-quehumano é devolvido à Humane Society para ser adotado por alguém que não esteja encarcerado (Departamento de Correções, Dakota do Sul, 2020). Blue Bird conclui a sua mensagem "perguntando-se se as aves sonham", e de fato sonham (Margoliash, 2005). Embora ele não possa dar uma longa caminhada devido à sua prisão, ele me incentiva a fazê-la.

Nas visões de mais-que-humanos que o Blue Bird compartilhou comigo, suas descrições são frequentemente vívidas e alegres. Ele me disse que, embora o salário não seja tanto quanto para alguns dos outros empregos na prisão, ele trabalha como zelador porque gosta de ficar ao ar livre. Ao trabalhar, o que a prisão considera uma atividade aceitável para as pessoas que estão presas, Blue Bird consegue garantir mais tempo fora de sua cela para observar ao ar livre. Em uma 
história que Blue Bird compartilhou comigo, o desafio e, em última instância, a vitória de ver um mais-que-humano - neste caso, a estrela da manhã - trouxe a ele uma enorme gratidão, e ele teria retribuído ao mais-que-humano se ele tivesse os meios.

Todo este mês estive caçando a estrela da manhã, certo? Eu simplesmente parava e procurava-a. E, por acaso voltei aqui em cima. Eu vivo uns cinco andares acima e lá estava ela, bem na minha janela. Lá estava ela. Era como se ela estivesse se movendo no céu. Lá estava ela, a estrela da manhã. Então, eu disse: Isto é para minha família, e isto é para Tria e para todas as pessoas que apoiam os presos, e para todos os banchees $^{11}$, e para todas as crianças e todas as pessoas idosas. Eu realmente gostaria de ter um pouco de tabaco para oferecer à estrela da manhã. Eu disse: Muito obrigado. Tenho observado a estrela da manhã desde que era menino. As pessoas (Lakota) costumavam nos ensinar: Você vai lá e cumprimenta aquela estrela da manhã. Eles diziam: Você diz olá, conta a ela seus problemas e conversa com ela. Cara, foi uma experiência poderosa. E eu saí esta manhã, imediatamente, e era meio que quase invisível no céu, mas eu apenas disse: Ei, você está aí". Eu disse: "Vejo você agora." (Blue Bird, 31 ago. 2020).

Quando Blue Bird finalmente avistou a estrela da manhã, ele respondeu de uma maneira Lakota, orando por seus parentes, apoiadores e banchees. Embora o termo banchee surja da cultura irlandesa, o luto profundo pela morte de um parente também é relevante para a avassaladora sensação de perda que uma pessoa pode sentir quando um membro da família ou amigo próximo é preso (Blue Bird, 31 ago. 2020). Blue Bird também ora por crianças e idosos que as epistemologias Lakota compreendem como sagrados e vulneráveis ao mesmo tempo (Blue Bird, 31 ago. 2020). Ele não pode oferecer tabaco - outro mais-quehumano - para a estrela da manhã, o que também é uma prática Lakota que representa reciprocidade e demonstra gratidão. Pessoas que estão encarceradas na Penitenciária do Estado da Dakota do Sul têm acesso muito limitado ao tabaco, apesar da Lei de Liberdade Religiosa dos Nativos Americanos de 1978, "que protege os direitos dos nativos americanos [incluindo aqueles que estão presos] garantindo [...] uso e posse de objetos sagrados" (42 U.S.C. § 1996). Presumivelmente para atender ao requisito legal, a prisão fornece às pessoas que estão encarceradas um

${ }^{11}$ Nota de tradução: banchees compreendem figuras mitológicas, da família das fadas, designadas como mensageiras da morte. 
substituto. A mistura que inclui algum tabaco, mas é composta principalmente por casca de salgueiro vermelho (Rosado, 2020). No entanto, os nativos americanos aprisionados com quem falei não a consideram que essa mistura seja tabaco (Blue Bird, 31 ago. 2020).

Apesar do ambiente repressivo da prisão, há momentos em que Blue Bird é capaz de praticar trocas significativas com mais-que-humanos.

Na prisão, agora estou trabalhando com oito conjuntos individuais de formigas. Eu tenho quatro na parede leste com as quais trabalho, e essas, elas cavam lá. Elas são formigas pretas. Elas cavam muito. As que estão mais próximas da prisão apenas vagueiam. Elas vivem lá no concreto e na areia. Tem formigas doentes lá. Eles pararam de comer toda a comida. O favorito delas são bolinhos de queijo, quando eu os esmago. Eu pego biscoitos e os esmago. Essa é a comida favorita delas aqui. Elas vêm e começam a escavar tudo. Peguei muito chocolate, muitos biscoitos e muita pipoca. Elas enlouquecem com pipoca. Eu amasso a pipoca e, agora, elas pararam de comer. Elas sobem e pegam toda a comida e a levam de volta para baixo. Eu observei formigas durante toda a minha vida, mas nunca formigas de prisão. Algumas das pessoas que trabalham aqui têm que andar pelos pavilhões e disseram: "O que você tem aí, uma fazenda de formigas?" Eu disse: "Não, não. Eu as estudo", eu disse. "Eu uso a poeira que elas trazem pra cá para fins de cura". Eles dizem: "Sério? Sério?" Eu digo: "Oh sim. Isso é o que os antigos costumavam fazer." (Blue Bird, 2020).

Refutando que ele tenha uma fazenda de formigas, na qual estão contidos os mais-que-humanos, Blue Bird estuda cuidadosamente as formigas em seu ambiente natural (Blue Bird, 18 set. 2020). Ele traz para as formigas uma variedade de petiscos e guloseimas diferentes, que ele esmaga para elas, provavelmente um gesto atencioso que torna mais fácil para as formigas comerem e transportarem a comida (Blue Bird, 18 set. 2020). Ao declarar: "Eu observei formigas durante toda a minha vida, mas nunca formigas de prisão" (Blue Bird, 18 set. 2020), Blue Bird sugere que talvez algumas de suas interações com as formigas sejam inspiradas pelas conversas que tivemos sobre interconexões humanas e mais-que-humanas (Blue Bird, 18 set. 2020). Embora as inter-relações humanas e mais-que-humanas fossem um dos meus interesses de pesquisa antes de conhecer Blue Bird, essas conversas também foram influenciadas pelas histórias que ele compartilhou comigo. De fato, porque ele me perguntou sobre os mais-que-humanos de onde 
eu moro e de outras visões e experiências além dos muros da prisão, eu também me encontro mais em sintonia com as observações e ocorrências, então posso fornecer detalhes que ele pode achar interessante.

Enquanto Blue Bird parece apreciar o que eu lhe digo, ele frequentemente invoca interações com humanos e mais-que-humanos para além dos muros da prisão por meio do que ele chama de "deriva":

Costumo pensar nos cavalos que vagueiam livres e selvagens enquanto vivem e sobrevivem dia após dia. Eu me pergunto como seria segui-los e fazer um documentário sobre eles com palavras e câmeras de vídeo? Sempre faço viagens até eles a partir daqui da prisão para visitá-los com seus líderes e seus bandos. (Blue Bird,11 jan. 2020).

\section{Deriva}

Por meio da performance decolonial de "deriva", na qual ele imagina, viaja e habita outros territórios, Blue Bird aprendeu a transcender as paredes da prisão. Embora todas as ações humanas sejam encarnadas, o conceito de "deriva" de Blue Bird é uma contribuição importante, na medida em que teoriza a multiespacialidade das práticas incorporadas. Blue Bird desenvolveu essa tática de sobrevivência como resultado de seu aprisionamento e sua incapacidade de sonhar desde 1979, quando foi espancado por vários homens em uma rua de Chicago. Nas palavras do Blue Bird, ele teve que aprender a "sonhar de outra maneira" (Blue Bird, 4 out. 2020). Ele escreveu:

Eu consigo derivar com facilidade. Dê-me algumas palavras para me fazer seguir na direção que você quer que eu vá. Deriva é uma técnica que uso para estar no mundo aqui, lá e em qualquer lugar. Posso atravessar muitos padrões de voo e fusos horários em questão de minutos. As palavras transportam o que sou capaz de fazer em inscrições que descrevem cor e textura até os ossos do ser criativo. (Blue Bird, 3 out. 2020).

Blue Bird articula sua proficiência: "Eu posso derivar facilmente," e "Eu posso cruzar muitos padrões de voo e fusos horários em questão de minutos" (Blue Bird, 
3 out. 2020). De fato, um sentido de "deriva" delineia uma habilidade na qual uma pessoa cria intencionalmente condições que permitem que ela exerça controle e maestria. No que se refere ao automobilismo, "deriva" descreve uma curva realizada por motoristas para perder tração enquanto mantém o controle do veículo (O’reilly e Eckert, 2014). Por meio da prática de "deriva”, que implica uma perda proposital de controle, quando Blue Bird é levado por seus sonhos, ele "abre mão das condições atuais para se mover em seus próprios termos e viajar para outro lugar" (Mattingly, 2020). Encontrar uma forma alternativa de sonhar - apesar da violência que the foi infligida e que o fez perder essa capacidade - é outra camada da expertise de Blue Bird.

Na descrição do Blue Bird, "deriva” também sugere as maneiras como essa prática decolonial pode ocorrer em relação aos humanos: "Dê-me algumas palavras para me fazer ir na direção que você quer que eu vá" (Blue Bird, 3 out. 2020). O termo "deriva" implica ainda mais interconexões humanas e mais-quehumanas e pode ser ativado para fortalecer essas relações. Outra denotação de "deriva” é ser compelido ou transportado, geralmente pela água, vento ou ar, todos eles mais-que-humanos, que influenciam a direção e o movimento do ser que é compelido ou transportado (Merriam-Webster, 2020). No contexto humano e mais-que-humano, então, "deriva" sugere a força de não humanos que podem guiar o movimento humano, o que desafia o antropocentrismo. Blue Bird articulou que "deriva” pode ocorrer por meio de processos artísticos. Embora na passagem anterior, Blue Bird identifique especificamente "palavras", ele também é um artista visual e uma vez descreveu a experiência da pintura para mim como "Estou realmente voando." (Blue Bird, 10 jul. 2020).

Blue Bird também pratica "deriva" ao ouvir música e ao dançar, e frequentemente compartilha os títulos de suas canções favoritas comigo. Em 2017, Global Tel Link, uma empresa de telefonia da prisão, forneceu a todas as pessoas que foram/estão presas no Departamento de Correções de Dakota do Sul um tablet eletrônico, que lhes dá acesso pago a "e-books, jogos, streaming de música, telefonemas mais longos com a família e fácil acesso aos documentos da prisão" (Hult, 2017). Ao firmar contratos com a prisão, a empresa lucrou com a violência 
do encarceramento e, consequentemente, de grupos vulneráveis. Blue Bird expressou um sentimento de conflito interno em comprar na empresa, que é cara, principalmente considerando os salários das pessoas que estão presas. Ainda assim, ele reconhece que a empresa oferece serviços significativos para ele e outras pessoas que estão encarceradas. Ele compartilhou:

Estou encontrando música no tablet. Eu estou indo para a Ásia, África. Eu estou indo para as ilhas oceânicas. Eu estou indo para o Japão... O tablet está em nossas mãos cerca de 95\% do tempo. E eu realmente não queria, mas apenas disse: ok, vou aceitar porque custa cerca de 20 dólares por mês... A única razão pela qual faço isso é para poder estar sozinho naquele clima de dança, o tempo todo, todos os dias, 24 horas por dia, 7 dias por semana. Gosto de ouvir diferentes palestrantes ao redor do mundo. Diferentes ativistas e pessoas que lutaram pela liberdade em suas vidas. (Blue Bird, 16 ago. 2020).

O tablet ajuda na "deriva" de Blue Bird e sua música inspira seu "clima de dança". Embora Blue Bird expresse que ele aprecia sua solidão neste estado, ele também parece encontrar semelhanças entre ele e "diferentes ativistas e pessoas que lutaram pela liberdade" (Blue Bird, 16 ago. 2020), o que ilustra a forma como o Blue Bird conceitua os movimentos sociais como sendo internacionais.

O enquadramento de "deriva" de Blue Bird destaca ainda mais os limites do controle carcerário e das políticas punitivas. Outro sentido para "deriva" é "moverse ou flutuar suavemente e sem esforço" (Merriam-Webster, 2020), o que no contexto humano, pode significar prazer e relaxamento - por exemplo, como as experiências de Blue Bird ao ouvir música. Os agentes penitenciários não conseguem administrar totalmente a movimentação das pessoas presas nem o gozo que elas podem experimentar milagrosamente dentro das condições de morte social (Cacho, 2012). A Penitenciária do Estado da Dakota do Sul determina espaços e horários específicos - embora muitas vezes limitados - para que as pessoas presas possam se envolver em atividades que podem ser consideradas suaves, sem esforço, prazerosas e relaxantes - como durante a recreação, cerimônias e powwows ${ }^{12}$ (Merriam-Webster, 2020). No entanto, tais momentos e

${ }^{12}$ Nota de tradução: o termo refere-se às cerimônias festivas de povos originários estadunidenses. 
as experiências agradáveis que eles podem produzir, parecem, em grande parte, a antítese das formas como os corpos e as mobilidades são restringidos no contexto carcerário.

Por meio da "deriva", o espírito de Blue Bird compareceu a Carceral Liberation? A Native American Prison Art Show, da qual fiz a curadoria no início de outubro de 2019, por ocasião do Dia dos Povos Nativos. A exposição ocorreu em um estúdio comunitário nas terras Tongva, ou no que costuma ser conhecido como Los Angeles. A mostra de arte apresentou de forma proeminente seis desenhos do Blue Bird, juntamente com obras de arte e palavras de povos nativos que estão/foram presos principalmente na Penitenciária do Estado da Dakota do Sul e na Prisão Feminina da Dakota do Sul. Mais tarde naquele mês, o Blue Bird me enviou uma mensagem - uma das primeiras que recebi dele por meio do sistema online - intitulada Cavalos da liberdade.

Antes da exposição começar, enviei meu espírito guerreiro para ajudar sempre que necessário. Dei-lhe ordens estritas para ficar quieto e trabalhar sem perguntar. Ele cruzou todas as rodovias entre aqui e Denver, onde pegou a I-70 oeste para as montanhas e acampou durante a noite. Ele não conseguia acreditar em como esta área é convidativa, com os pinheiros e as formações rochosas sólidas. Ele dormiu bem.

Pegar carona ainda pesa em sua vida. Eu disse a ele para se comunicar com todos os cavalos que visse. Ele cruzou para a região ao norte de São Francisco na manhã seguinte, onde fez café caseiro fervido em uma panela no fogo e se preparou para realmente atravessar a ponte Golden Gate pela primeira vez em sua vida. Dali, ele pegou a rodovia mais próxima do oceano e chegou ao seu grupo exatamente quando o sol estava se pondo. Todo mundo ficava olhando para ele porque ele usava uma jaqueta verde do exército e calça jeans. Seu cabelo estava em um rabo de cavalo e sua faixa vermelha escura significava seu status como um guerreiro Oceti Sakowin de alto escalão.

Ele queimou muito hante blaska (cedro plano) e cantou uma música para homenagear todos vocês. Ele cumprimentou você pessoalmente e trouxe algumas histórias sobre a prisão. Você mostrou a ele toda a arte, trabalhos com contas, textos e criações talentosas. Ele pediu para olhar a pedra que você guarda na bolsa. Depois de visitar todos e apertar as mãos, ele se sentou em uma cadeira para descansar. Ele vai ficar até o fim da exposição. (Blue Bird, 31 out. 2019).

Ilustrando a multiespacialidade da "deriva" e desafiando os limites do 
controle carcerário, a narrativa de Blue Bird discute como ele envia seu espírito guerreiro para a mostra de arte, dando a seu espírito "ordens estritas para ficar quieto e trabalhar sem perguntar" (Blue Bird, 31 out. 2019). Blue Bird representa a si mesmo como uma figura soberana e autoritária, criando assim as circunstâncias que the permitem a "capacidade de fazer escolhas, até mesmo escolhas que oferecem a ilusão de controle", o que de acordo com Toch, é uma "necessidade humana fundamental" (Toch, 1998). No entendimento dos nativos, um guerreiro é uma pessoa espiritualmente desenvolvida e disciplinada, dedicada a proteger parentes humanos e mais-que-humanos - e não necessariamente alguém que se envolve em lutas físicas (Peltier, 1999; Denetdale, 2007); consequentemente, Blue Bird diz ao seu espírito para "ajudar onde for necessário” (Blue Bird, 31 out. 2019). Antes de sua prisão, Blue Bird era um ávido por pegar caronas e seu espírito continua esta tradição por meio da "deriva".

No geral, Blue Bird imagina uma jornada agradável na qual seu espírito é visto e mantém um bom relacionamento com uma variedade de seres mais-quehumanos e é admirado por humanos. Ele é uma figura misteriosa, chegando "exatamente quando o sol estava se pondo" (Blue Bird, 31 out. 2019), mas também identificável como um "guerreiro Oceti Sakowin de alto escalão" (Blue Bird, 31 out. 2019), vestindo trajes e um penteado que evoca os líderes do Movimento Indigena Americano nas décadas de 1960 e 1970. Quando ele chega à exposição, ele se envolve em atos de generosidade e reciprocidade: queimando hante blaska13 e cantando a prova de honra dos costumes Lakota (Blue Bird, 31 out. 2019). Pela sua saudação pessoal e pela pedra que ele pede para olhar na minha bolsa, fica claro que somos amigos e ele tem conhecimento interno sobre mim (Blue Bird, 31 out. 2019). No powwow que participei na Penitenciária Estadual de Dakota do Sul em setembro de 2019, Blue Bird me presenteou com trinta e cinco lindas pedras que ele havia coletado do pátio da prisão, lavado à mão e levado para a cerimônia. A pedra a que ele se refere na história é talvez a mais espetacular, é lisa, redonda e tem o tamanho e a forma de um ovo; eu disse a ele que a carrego comigo na bolsa.

${ }^{13}$ Nota de tradução: hante blaska corresponde a uma erva sagrada utilizada pelos Lakota em cerimônias. 
A prisão não apenas separa os humanos de mais-que-humanos, mas também limita severamente as interações entre humanos, sendo que a prática de "deriva" de Blue Bird pode se opor a essas duas limitações por meio da imaginação e da narração de histórias. Em outra narrativa sobre a exposição, intitulada $O$ Retorno, Blue Bird se aprofunda ainda mais nos passeios turísticos que faria, nas conversas que teríamos enquanto ele estivesse em Los Angeles e em sua jornada para casa.

\begin{abstract}
Eu gostaria que você me desse uma carona até a fronteira com o Oregon. No caminho, conversaríamos sobre sempre ter uma atitude de gratidão. Eu responderia a todas as suas perguntas. Você riria do meu humor. Em Seattle, pegaria a I-90 e estaria em Black Hills em quase setenta horas, dependendo do tráfego. Rapid City para Sioux Falls é fácil. (Blue Bird, 1 nov. 2019).
\end{abstract}

A “atitude de gratidão" de Blue Bird, apesar de tolerar trinta e seis anos de prisão, evidencia, para mim, sua notável força (Blue Bird, 1 nov. 2019). Imagino que, na fronteira de Oregon, nos separaríamos, e o Blue Bird encontraria outra pessoa para lhe dar uma carona (Blue Bird, 1 nov. 2019). Ele omite nossas despedidas; não há necessidade de tristeza ou de considerar o que significaria cessar nossas comunicações (Blue Bird, 1 nov. 2019). Como muitas pessoas que cumpriram sentenças longas sabem, a prisão pode afetar negativamente os relacionamentos (Genty, 2002). Em nossas conversas, Blue Bird já me pediu para ser sua amiga nas próximas décadas, e eu aceitei. Compromissos de longo prazo são centrais para as metodologias de pesquisa nativas. (Mithlo, 2012).

Na cena que o Blue Bird retrata, eu "riria de seu humor" (Blue Bird, 1 nov. 2019) e, de fato, muitos pesquisadores em estudos nativos e prisionais identificaram a leveza como uma tática de sobrevivência importante (Deloria, 1969; Terry, 1997). Blue Bird também trouxe humor em algumas das conversas que tivemos. Uma vez, para nossa diversão, ele brevemente me trouxe para sua "deriva". Atendi o telefone como sempre faço:

"Ei, George. Como você está?"

Falando rapidamente, ele respondeu: "Muito bem. Muito bem. Adivinhe onde estou?" 
“Onde?” Eu perguntei.

Ele respondeu: "Estou nas montanhas da Palestina. Estou ajudando meus irmãos a lutar contra os israelenses. Eu fui enviado para cá por uma recomendação especial."

Comecei: "Puxa, bem, é ..."

Ele interrompeu: "Não. Eu queria. Eu queria”.

Eu disse: "Parece um trabalho perigoso".

Ele respondeu: "Bem, eu sou um homem perigoso. Como você está hoje? Como você está?.” ( Blue Bird, 18 jun. 2020).

Blue Bird me fala frequentemente sobre os palestinos e os considera companheiros dos povos nativos, que também estão lutando contra a colonização em andamento e seus efeitos deletérios, incluindo o confinamento. Blue Bird é novamente um guerreiro de alto escalão, desta vez sob uma "ordem de especialista" (Blue Bird, 18 jun. 2020). Depois que Blue Bird afirma que é um homem perigoso, ele rapidamente muda de assunto e gentilmente volta sua atenção para mim. Embora naquele ponto da conversa Blue Bird não estivesse mais vagando, também é possível que ele tenha mudado de assunto devido aos estereótipos duradouros que envolvem não apenas as pessoas que estão presas, mas também os homens nativos como "perigosos." (McKegney, 2014).

Embora a "deriva", a troca de mensagens e realização de métodos de pesquisa nativa possa fortalecer as relações entre humanos, a prisão monitora e regula fortemente essas interações e pode proibir a qualquer momento as pessoas que entram na prisão de se comunicarem com as pessoas que estão encarceradas. Certa vez, participei de uma conversa em que um funcionário voluntário da Penitenciária do Estado da Dakota do Sul me contou sobre pessoas que estão/foram encarceradas que trocaram mensagens com pessoas que não estão presas para planejar sua fuga. Fui lembrada de que, para Blue Bird e eu continuarmos a fazer nosso trabalho juntos, é importante interagimos de tal forma que os funcionários da prisão me percebam como profissional e não como uma ameaça. 
Às vezes, na "deriva” que o Blue Bird compartilhou comigo, parecia que ele mesmo, ou aspectos de seu corpo, se transformavam em algo mais-que-humano. Pouco depois de eu ter comparecido a um powwow na Penitenciária do Estado da Dakota do Sul, ele me enviou uma série de mensagens e, junto com cada uma delas, cavalos. Blue Bird gosta de cavalos e uma vez me escreveu que "Sonhos com cavalos são os melhores que se pode ter". Em uma mensagem intitulada $O$ quarto cavalo, ele escreveu:

O quarto cavalo saiu dos portões da prisão esta manhã, antes do sol nascer. Ele é um corcel Lakota de raça pura das terras natais de Pine Ridge, é selvagem e nunca foi montado. Sua pelagem é de um amarelo profundo e sua crina e cauda são pretas com fios longos. Ele tem manchas vermelhas e azuis em ambos os quadris. Os de carga têm corpos fortes e abaixam a cabeça para sentir o cheiro da terra em busca de inimigos e perigo. Ele cresceu sem um nome e nunca teve uma família.

Ele vai chegar ao extremo norte da Califórnia e se encontrar com duas éguas que foram roubadas de suas famílias durante os incêndios. Ele prometeu levá-las de volta à Los Angeles e reuni-las.

Ele thes dará uma rota segura ao longo do oceano. Seus cascos irão criar uma história de proteção nas areias. Ele gosta de ajudar os outros. Está em seu sangue. Ele é um bom cavalo.

Quando ele chegar até você, estará cansado e com fome. Queime um pouco de cedro vermelho seco e esfregue-o com a fumaça. O aroma é doce e pode imortalizar tudo. Deixe-o dormir alguns dias. A Horse With No Name da banda America é uma canção que o permite experimentar sonhos que ele não pode ter. Isso o mantém vivo. O cedro é do tipo com pequenos mirtilos presos em seus ramos.

Mostre a ele sua coleção de botas. Deixe-o se encantar com suas favoritas. Fale com ele. Convide-o para ficar com você na noite do dia 10, quando a lua cheia iluminar o céu. (Blue Bird, 1 jan. 2020).

Como Blue Bird, o quarto cavalo é Lakota "das terras natais de Pine Ridge" e não pode sonhar (Blue Bird, 1 jan. 2020). Além disso, como o Blue Bird, o quarto cavalo "gosta de ajudar os outros." (Blue Bird, 1 jan. 2020).

\section{Ativando futuros e liberdade}

Dadas as formas com que frequentemente são criminalizadas e proibidas as 
práticas Nativas nos Estados Unidos - isto é, a liberdade dos povos indígenas é punida - decretar futuros Nativos é um ato decolonial. Além de cultivar conexões com mais-que-humanos e "deriva”, Blue Bird também contribui para o futuro e a liberdade dos nativos por meio da organização coletiva, do trabalho árduo e da persistência, de doações e de práticas artísticas. Por vezes, ele faz esse trabalho como presidente do Conselho de Tribos dos Nativos Americanos, que se baseia diretamente nas performances decoloniais de outros ativistas Lakota, muitos dos quais estão/foram encarcerados em terras Lakota na década de 1970 (Blue Bird, 10 jul. 2020). Em dezembro de 2019, Blue Bird providenciou para que os Lakota que estão presos recebessem um tipith. Ele explicou:

Perdemos o rumo. Temos muito que reconstruir. Trabalhei com nosso pessoal de fora e agora temos um Lakota tipi pronto para entrar. Este será o primeiro na história das prisões da Dakota do Sul. Ele será muito honrado aqui dentro. Algumas pessoas aqui estão dizendo que ele não pode entrar. Eu digo que pode. Lancem um pouco de tabaco para nós. (Blue Bird, 3 nov. 2019).

Blue Bird expressa que "nós" - presumivelmente pessoas que estão encarceradas - "perdemos o rumo" e "temos muito o que reconstruir" (Blue Bird, 3 nov. 2019). Ele também sugere que participar de práticas culturais Lakota - neste caso, ter acesso a um Lakota tipi - fornecerá um antídoto para esses problemas (Blue Bird, 3 nov. 2019). Blue Bird parece animado com o fato de o tipiser o primeiro na prisão e imagina como será uma vez lá dentro (Blue Bird, 3 nov. 2019). "Algumas pessoas" as quais o Blue Bird se refere são funcionários da prisão e talvez voluntários, alguns dos quais me expressaram seu aborrecimento pelo fato de Blue Bird muitas vezes fazer arranjos sem primeiro solicitar ou proceder por meio dos canais adequados. Embora eu possa entender essas frustrações, que criariam obstáculos no trabalho de alguém, para mim, as ações de Blue Bird também refletiram sua persistência inflexível e ainda são outra tática de sobrevivência que ele adota. Em vez de pedir permissão - provavelmente sabendo muito bem que o 
tipi viola os regulamentos da prisão - Blue Bird criou condições que colocaram pressão adicional sobre as autoridades prisionais. Os Lakota que não estavam presas já haviam conseguido e trazido o tipi e os convidados para o powwow também estavam cientes da situação. Blue Bird me instruiu a "lançar um pouco de tabaco" como uma oferta para ajudá-lo a alcançar seus objetivos. (Blue Bird, 3 nov. 2019).

Blue Bird frequentemente me pede para fazer um trabalho, o que em muitos casos também pode ser conceituado como uma contribuição para a liberdade e o futuro de Blue Bird e de outros nativos que estão/foram encarcerados. Eu fico feliz em fazer o que posso, porque respeito e valorizo Blue Bird, e ele me presenteou muito - incluindo as inúmeras histórias e o conhecimento cultural Lakota que compartilhou comigo. No powwow de dezembro de 2019, ao qual compareci na Penitenciária do Estado da Dakota do Sul, ele providenciou para que eu recebesse um nome Lakota na cerimônia, Tasunke Olotapi Win (Cavalos emprestam sua mulher). Ao longo dos três anos em que participei dos powwow na prisão, Blue Bird, junto com outros homens nativos que estão/foram encarcerados, me honrou com vários presentes, incluindo duas colchas de estrelas, quatro penas e plumas de águia, pedras, quillwork mocassins ${ }^{15}$ para uma de minhas filhas, desenhos e vários itens com miçangas para mim e membros da minha família. Em muitos contextos culturais, o destinatário do presente tem responsabilidades para com o doador (Foster, 2019). Na verdade, Blue Bird frequentemente me pede para oferecer tabaco para as pessoas nativas que ele conhece e que já faleceram, e para fazer ligações para pessoas que não estão atualmente em sua lista de telefone - especialmente para expressar condolências em nome dos homens nativos que estão/foram presos. Ele também me pediu recentemente para entrar em contato com uma estação de rádio em uma das reservas Lakota para pedir que tocassem uma música em homenagem a uma pessoa falecida. No powwow que participei em setembro de 2019, fui presenteada, junto com a colcha de estrelas, com um lindo cartão que apresentava um dos desenhos do Blue Bird.

${ }^{15}$ Nota de tradução: calçado produzido artesanalmente por povos nativos estadunidenses, trabalhado a partir de pelos de porcos-espinhos. 
Assinado por mais de sessenta homens nativos que estão/foram encarcerados, o cartão declara:

TRIA,

SEJA SEMPRE UMA DEFENSORA DESTEMIDA

E UMA APOIADORA

DE NOSSA TRIBO

APRISIONADA

EM TODA PARTE DO MUNDO.

Desta forma, o próprio presente comunica a responsabilidade.

Blue Bird está empenhado em fazer oferendas pelo futuro e liberdade dos nativos, dentro e fora da prisão. Embora essa generosidade e doação possam ser entendidas como "vermelhas" - novamente, comunista - na estrutura abolicionista de Gilmore (Gilmore; Estes; Haley; Sepulveda, 2020), essas são atitudes e práticas fundamentais na cultura Lakota (Whirlwind Soldier, 1996). Estudos anteriores enfatizaram que as pessoas condenadas à prisão perpétua podem encontrar propósito em orientar e ajudar os outros Johnson and Dovrzanska, 2005, p. 36), e as performances e escritos de Blue Bird também ilustram isso. Durante o período da pandemia de COVID-19, a Penitenciária do Estado da Dakota do Sul proibiu cerimônias, powwows, e a entrada de voluntários e visitantes na prisão. Blue Bird e outras pessoas nativas encarceradas com quem conversei enfatizaram que as cerimônias e eventos realizados na prisão são essenciais para seu bemestar/sobrevivência. Como Blue Bird me escreveu:

Continuo procurando e buscando maneiras de ajudar nossos prisioneiros aqui. Parece que ainda poderemos ficar trancados por um longo tempo. Os meses de verão são os tempos mais difíceis para nós por causa do calor e das animosidades que estarão por toda parte. (Blue Bird, 1 nov. 2020).

Apesar dos desafios e limitações que o Blue Bird enfrentou e continua a suportar por causa de sua prisão, ele, no entanto, não cessa de buscar formas de ajudar os nativos fora da prisão. Antes do powwow de dezembro de 2019, do qual participei, ele me escreveu: 
Estou em uma missão difícil para encontrar trinta mochilas para dar às nossas crianças em nosso powwow em 7 de dezembro e gostaria que você me ajudasse. Desejo usar nosso estatuto 501 (c) (3) de organização sem fins lucrativos. Temos a aprovação de nosso comitê powwow para fazer isso. (Blue Bird, 23 mai. 2019).

Sabendo que eu não seria capaz de trazer mochilas para a prisão sem a aprovação das autoridades - não tenho nem permissão para trazer minhas chaves ou carteira para dentro - pedi permissão a eles. Eles me dissuadiram de conseguir as mochilas, dizendo-me que não havia nem perto de trinta crianças inscritas para o powWow.

Embora suas visões nem sempre sejam percebidas, Blue Bird continua a elaborar sonhos vívidos para o futuro, que constituem doações para os Lakota:

Um dos meus sonhos de guerreiro é oferecer uma grande refeição e um prêmio de quatro dias em Rapid City usando a carne de quatro búfalos. Eu quero fazer isso por todos os prisioneiros tribais e todos os sistemas de apoio que nos ajudaram a superar os tempos difíceis aqui nas penitenciárias de Sioux Falls, e onde quer que tenhamos cumprido pena. Eu gostaria que muitos cavalos estivessem lá. Depois que o sol baixar, poderíamos fazer muitas fogueiras e contar histórias. Nossos percursionistas chamariam todos os dançarinos. O suco de chokecherry ${ }^{16}$ estaria em toda parte. (Blue Bird, 14 jan. 2020).

O "sonho de guerreiro" de Blue Bird novamente se baseia no entendimento dos Lakota de um guerreiro como alguém que protege e eleva as pessoas (Blue Bird, 14 jan. 2020). Ele prevê uma grande reunião composta de humanos e maisque-humanos - onde comida e bebida são abundantes - compartilhando histórias, músicas e dança. Blue Bird também expressou a consciência de que, embora nem todos os seus sonhos se tornem realidade, ainda há valor em comunicar essas possibilidades a outras pessoas.

O pensamento místico e ambicioso de que poderíamos ser os cantores principais e colocar um grupo de pessoas juntas em uma banda e cantar para as pessoas apenas para se sentirem bem e adicionarem um pedaço de pura criatividade em tudo que é positivo, deixa minha atitude guerreira

${ }^{16}$ Nota da tradução: chokecherry é uma fruta conhecida como "cereja da Virgínia". 
cheia de calor e paixão. Este evento todo provavelmente nunca vai acontecer, mas foi bom transmiti-lo a você e ao mundo lá fora (Blue Bird, 31 jan. 2020).

Blue Bird descreve os efeitos enérgicos que seu sonho tem sobre sua "atitude de guerreiro" (Blue Bird, 31 jan. 2020). Ele compôs notadamente esta mensagem antes de nós colaborarmos neste documento. Embora nem toda visão de Blue Bird tenha sido realizada - pelo menos, não ainda - suas palavras e sonhos realmente circulam no mundo além da prisão.

Oração e, correlativamente, o sacrifício cerimonial - que também são formas de doação - podem ajudar a trazer futuros nativos à existência. Blue Bird compartilhou:

Winyan unkitawa kin maka ahomni iyuha waceunkciciyapi (Oramos por nossas mulheres em todo o mundo). Neste dia, todos os prisioneiros Oceti Sakowin na penitenciária principal em Sioux Falls, Dakota do Sul, fizeram laços, queimaram cedro vermelho e sálvia, conversaram, ofereceram muita água, cantaram e oraram por todas as nossas mulheres. Muitas delas estão sozinhas criando famílias e lutando para comprar alimentos. As coisas estão difíceis. Contas e credores estão por toda parte. A vida é dura. Nosso Tunkan Tipi (Lar dos Sagrados) estava cheio de nossos guerreiros e homens que se sacrificaram no calor e concluíram com respeito e coragem. Lembramos de nossas mulheres que precisam trabalhar em dois empregos para garantir que as necessidades de suas famílias sejam atendidas em todos os sentidos. Algumas delas não possuem veículos e precisam caminhar para fazer negócios. O amor puro que elas têm por seus filhos thes dá muitos motivos para nunca desistir.

Elogiamos nossas mulheres pelo trabalho que realizam. A vida pode ser cruel. As pessoas estão com pressa para atender às suas necessidades pessoais sem perceber nossas mulheres, que estão no limite por causa das pressões que estão constantemente sobre elas para comprar roupas, cozinhar, costurar e equilibrar seu afeto entre todos que moram em suas casas.

Tivemos uma boa cerimônia. (Blue Bird, 31 jan. 2020).

Blue Bird considera profundamente os desafios que as mulheres enfrentam em todo o mundo. Ele, "junto com todos os prisioneiros Oceti Sakowin" na Penitenciária do Estado da Dakota do Sul, homenageia as mulheres realizando 
práticas cerimoniais Lakota (Blue Bird, 31 jan. 2020). Blue Bird entende em primeira mão o poder das pessoas que oram por ele. Durante a pandemia de COVID-19, ele compartilhou:

Poder receber a ajuda espiritual e o apoio de todos os lugares significa que o fardo de estarmos presos longe de nossas cerimônias e danças é tremendamente aliviado. Sinto a força das orações e canções que as pessoas fazem por nós. Elas entram pelas paredes e cercas e se aproximam de nossos lugares sagrados. Eu os sinto quase o tempo todo. Às vezes ouço canções antigas e sinto a presença dos espíritos (Blue Bird, 1 jul. 2020).

Blue Bird destaca como a ajuda e apoio espiritual de outras pessoas alivia a violência da prisão, e de como ele pode transitar entre o presente e o passado.

A criatividade e as artes também são fundamentais para a sobrevivência de Blue Bird enquanto ele está preso, e, também podem funcionar como uma forma de doação. Em uma rara mensagem expressando os desafios que enfrentou enquanto estava preso, ele escreveu:

Eu ia realmente desistir do mundo lá fora. E eu apenas disse: Ei, se eu morrer, morro. Mas então, de uma forma ou de outra, voltei à vida. Minha arte me trouxe de volta, minha escrita, sabe o que quero dizer? Eu realmente gosto dessas coisas. Eu realmente gosto dessas coisas. E é isso que eu tenho agora. Eu quero ser capaz de colocá-las para fora. Então, elas estão encontrando seu caminho. (Blue Bird, 10 jul. 2020).

Blue Bird expressa a vitalidade das artes para o seu futuro (Blue Bird, 10 jul. 2020). De fato, Blue Bird não está sozinho em se sentir às vezes esmagado pela violência do aprisionamento. Depois de um powwow do qual participei na prisão, esperei em uma cafeteria vazia com um representante tribal voluntário, enquanto os funcionários da prisão realizavam uma contagem das pessoas que estão/foram encarceradas. Observei vários pôsteres com declarações, muitos com temas que podem ser considerados simultaneamente inspiradores e condescendentes - por exemplo: "Toda conquista começa com a decisão de tentar" e "Se você está cansado de começar de novo, pare de desistir". Todos os cartazes careciam de uma análise estrutural e, em vez disso, focalizavam a responsabilidade individual. 
Evidenciando os desafios do encarceramento, um dos cartazes afirmava: "Fale. Notifique a equipe se alguém estiver pensando em suicídio. Você pode quebrar o silêncio. Você pode fazer a diferença. Você pode salvar uma vida." O destaque deste sinal sugere as dificuldades que as pessoas que estão encarceradas experimentam e constrói aqueles que se reportam às autoridades sobre alguém que está considerando o suicídio como herói.

Dentre os imensos desafios do contexto carcerário, Blue Bird vê as artes como uma oportunidade de experimentar a emancipação - embora efêmera. Ele me escreveu: "A liberdade é feita de arte, música, dança, escrever, falar, permanecer ativo e da energia coletiva de ouvir" (Blue Bird, 17 jan. 2020). As artes também auxiliam o Blue Bird na "deriva" (Blue Bird, 3 out. 2020). Referindo-se à escrita em seu tablet, Blue Bird diz: "Escrever é auspicioso. Posso sentar aqui e viajar para outros mundos bem rápido. Estamos limitados no espaço. Posso facilmente criar centenas de páginas" (Blue Bird, 1 nov. 2019). Blue Bird também articula como a "deriva" permite a ele "ser estratégico e lógico", o que desafia as noções eurocêntricas que colocam a imaginação em conflito com o intelecto: "Sempre que Blue Collar Man (Long Nights)" e All Along The Watchtower"s entra no meu campo de escuta, saio da prisão para lugares de liberdade e me permito ser estratégico e lógico" (Blue Bird, 14 jan. 2020). A declaração do Blue Bird também dá a entender que a prisão - um lugar em que crueldade, punição e violência são "senso comum" - é em si ilógica.

De acordo com o Blue Bird, as artes também contribuem para a liberdade e o futuro porque essas práticas têm possibilidades coletivas e transformadoras: "As palavras nos levarão longe e deixarão milhares de histórias positivas para que outros aprendam e se tornem indivíduos melhores" (Blue Bird, 29 mai. 2020). Ele também compartilhou: "Muitos dos escritores poderiam viver sua escrita à sua própria maneira. Então, é sobre isso que gosto de estudar na escrita. Mas ainda mais, como escrever e o que fazemos com a nossa escrita, e como isso muda o

${ }^{17}$ Nota da tradução: Blue Collar Man (Long Nights)é uma canção da banda estadunidense de rock Styx, lançada em 1978, como parte de seu álbum Pieces of Eight.

${ }^{18}$ Nota da tradução: All Along the Watchover é uma canção de Bob Dylan, lançada em 1967 no álbum John Wesley Harding. 
mundo" (Blue Bird, 28 set. 2020). Para Blue Bird, essas possibilidades coletivas e transformadoras se estendem para além dos humanos, novamente combatendo as lógicas eurocêntricas e antropocêntricas:

Escrever é meu segundo nome. Eu sei como fazer as coisas ganharem vida em termos de cor e de tempo. Os cavalos me motivam. Eu os vejo em bandos. Os garanhões e os líderes dominantes competem pelo direito de tomar todas as decisões. Eu reconheço sua hierarquia. Os cavalos são singularmente místicos e românticos. Aqueles que usam de alta velocidade são minhas melhores escolhas. Alguns são quietos e outros são loucos. Os cavalos são ousados e cuidam uns dos outros. Eles sempre sabem o que fazer. (Blue Bird, 4 jan. 2020).

\section{Wakanjeja (Criança ou Presente Sagrado)}

Quando conheci Blue Bird pela primeira vez em dezembro de 2017 em um powwow para homens nativos que estão/estavam encarcerados e seus parentes, eu estava grávida de sete meses de minha filha mais nova. No powwow e com minha permissão, Blue Bird orou publicamente por mim e minha filha ainda não nascida. Em Lakota, "wakanjeja”, é uma palavra composta que significa "criança”; "Wakan" significa "sagrado" e "jeja" significa "presente" (Soto, Handboy, Supranovich e Weiss, 2019, p.92)19. Então, para os Lakota, uma criança é um presente sagrado, e parece-me que dons sagrados também devem ter conhecimentos sagrados.

Numa noite de verão, cerca de dois meses antes de começar a escrever este artigo, em meio à pandemia de COVID-19, fui dar uma caminhada com minhas crianças, que na época tinham três e dois anos. Durante a pandemia, fazemos caminhadas em família quase todas as noites como parte de nossa rotina de cuidados. Quando minhas crianças e eu paramos para descansar, a mais nova, acidentalmente, começou a brincar em um formigueiro vermelho. As formigas estavam mordendo seus pés, dentro dos sapatos, e ela chorava. Eu já podia ver os vergões vermelhos se formando quando rapidamente tirei seus sapatos. Depois

19 Um falante fluente da língua Lakota, Blue Bird compartilhou: "Wakanjeja significa sagrados (seres espirituais)." (Blue Bird, 11 out. 2020). 
que eu tirei a última formiga de seu pé e ela a viu fugir, ela lhe disse: "Eu te amo".

Não tendo certeza de tê-la entendido corretamente, perguntei a ela: "Você ama a formiga?"

Ela respondeu: "Sim".

Eu disse: "Mas ela mordeu você".

Ela refletiu: "Mas eu também acho isso bom."

Baseando-me no conhecimento sagrado de meu presente sagrado, eu me pergunto o que significaria reconhecer e honrar a santidade de todos os seres mesmo quando eles nos ferem? E se isso fosse a norma e não a exceção? Que tipo de sociedade poderíamos sonhar, ensaiar, transformar em existência?

Em seu trabalho sobre o abolicionismo prisional, Gilmore também reconhece as relações vitais e geradoras entre humanos e mais-que-humanos (Kushner, 2019; Gilmore; Estes; Haley; Sepulveda, 2020). Nas lutas entrelaçadas por justiça social e abolicionismo, Gilmore expressou que as pessoas devem se tornar montanhas (Gilmore; Estes; Haley; Sepulveda, 2020). Inspirado pelas palavras de Blue Bird, gostaria de sugerir que as pessoas devem se tornar montanhas não apenas como um meio de garantir a justiça social, mas também para evocar a força e a sustentação para curar e persistir (Gilmore; Estes; Haley; Sepulveda, 2020). Concluo este artigo com um apelo à ação feito por Blue Bird:

Algum tempo atrás, eu fiz um terrível mergulho de corpo inteiro jogando softball e me machuquei muito. Eu quebrei algumas costelas e abri meu punho esquerdo. Alguns dias atrás, um de nossos rapazes me atacou com um furto de base. Eu o tirei e rasguei meu dedo mindinho direito.

Disseram-me para ir ao hospital. Eu não posso. Eu sou um auto curador.

Gosto de usar a terra e os nutrientes finos que as formigas trazem da terra onde vivem. É uma honra vê-las subir aos milhares quando coloco algo doce. Elas são meticulosas em suas habilidades. Elas estão cheias de criatividade e sabedoria. Aprendi as propriedades da cura espiritual das formigas quando era pequeno, com os mais velhos da minha tribo. Eu costumava assistir vovô e vovó pegando a sujeira e curando pessoas. [...] A cura que precisa acontecer não virá até mim. Preciso da tua ajuda. Envie-me o poder do oceano da maneira como você os conhece nas profundezas de sua vida. 
Isso me trará de volta. A cura virá através das montanhas e me alcançará aqui na prisão. (Blue Bird, 1 jul. 2020).

Como os 10,35 milhões de pessoas em todo o mundo que estão atualmente presas (Walmsley, 2016), Blue Bird precisa de sua ajuda e de um movimento internacional crescente para sonhar, ensaiar e colocar em prática um mundo que cuide - e não condene - dos nossos mais estruturalmente vulneráveis. Quando os pássaros sonham, acreditamos que os engaiolados sonham com a liberdade.

\section{Referências}

American Indian Religious Freedom Act. U.S. Code 42 (1996), § 1, Aug. 11, 1978, 92 Stat. 469.

BLUE BIRD. Comunicação pessoal, 30 de outubro de 2019, Dakota do Sul, Estados Unidos.

31 de outubro de 2019.

1 de novembro de 2019.

3 de novembro de 2019.

1 de janeiro de 2020 .

4 de janeiro de 2020.

5 de janeiro de 2020.

11 de janeiro de 2020 .

12 de janeiro de 2020.

14 de janeiro de 2020 .

17 de janeiro de 2020 .

31 de janeiro de 2020.

5 de fevereiro de 2020.

23 de maio de 2020.

29 de maio de 2020.

1 de junho de 2020.

9 de junho de 2020.

21 de junho de 2020.

1 de julho de 2020.

10 de julho de 2020.

1 de outubro de 2020.

3 de outubro de 2020, Dakota do Sul, Estados Unidos.

BLUE BIRD. Ligação telefônica, 18 de junho de 2020, Dakota do Sul, Estados Unidos. 
10 de julho de 2020.

30 de julho de 2020.

16 de agosto de 2020.

31 de agosto de 2020.

18 de setembro de 2020.

28 de setembro de 2020.

4 de outubro de 2020.

BRAULT, Emily R. Sweating in the Joint: Personal and Cultural Renewal and Healing Through Sweatlodge Practice by Native Americans in Prison. Nashville, 2005. Tese (Doutorado) - Vanderbilt University.

$\mathrm{CACHO}$, Lisa Marie. Social Death: Racialized Rightlessness and the Criminalization of the Unprotected. New York: New York University Press, 2012.

CREWE, Ben; HULLEY, Susie; WRIGHT, Serena. Swimming with the tide: Adapting to long-term imprisonment. Justice Quarterly, v. 34, n. 3., p. 517-541, 2017.

CRITICAL RESISTANCE. Dylan Rodriguez, "Abolition Is Our Obligation". 15 de setembro de 2017.2 Disponível em <https://www.youtube.com/watch?v=JXFO4Hcw9HQ>. Acesso em: 14 out. 2020.

DAVIS, Angela. The Fallacy of Prison Reform. Lecture at Keene State College, 30 de setembro de $2015 . \quad$ Disponível em <https://www.youtube.com/watch?v=LfnbnTsOr-M>. Acesso em: 14 out. 2020.

DELORIA, Vine Jr. Indian Humor. In: Custer Died For Your Sins: An Indian Manifesto. New York: Macmillan Press, 1969.

DENETDALE, Jennifer Nez. Reclaiming Diné History: The Legacies of Navajo Chief Manuelito and Juanita. Tucson: University of Arizona Press, 2007.

FLANAGAN, Timothy J. Dealing with long-term confinement: Adaptive strategies and perspectives among long-term prisoners. Criminal Justice and Behavior, v. 8, n. 2, p. 201-222, 1981.

FOSTER, Susan Leigh. Valuing Dance: Commodities and Gifts in Motion. Oxford: Oxford University Press, 2019.

GENTY, Philip M. Damage to family relationships as a collateral consequence of parental incarceration. Fordham Urban Law Review, v. 30, 2002.

GILMORE, Ruth Wilson; CRISPINO, Azzurra. The Case for Prison Abolition: Ruth Wilson Gilmore on COVID-19, Racial Capitalism \& Decarceration. Democracy Now, United States, n. 5 may 2020. Disponível em <https://www.democracynow.org/2020/5/5/ruth wilson gilmore abolition coron avirus>. Acesso em: 9 dez. 2020. 
GILMORE, Ruth Wilson; ESTES, Nick; HALEY, Sarah; SEPULVEDA, Charles. Abolition on Stolen Land. Panel Discussion, University of California Los Angeles, 9 oct. 2020.

GRANT, Elizabeth. PRISON ENVIRONMENTS AND THE NEEDS OF AUSTRALIAN ABORIGINAL PRISONERS. Australian Indigenous Law Review, v. 12, n. 2, p. 66-80, 2008.

HANLEY, Natalia; MARCHETTI, Elena. Dreaming Inside: An evaluation of a creative writing program for Aboriginal and Torres Strait Islander men in prison. Australian \& New Zealand Journal of Criminology, v. 53, n. 2, p. 285-302, 2020.

HULT, John. Inmate tablets have now been delivered to all South Dakota prisons. Argus Leader, United States, n. 28 jun. 2017. Disponível em<https://www.argusleader.com/story/news/2017/06/28/tablets-delivered-alldoc-facilities/432831001/>. Acesso em: 14 out. 2020.

JOHNSON, Robert; DOBRZANSKA, Anie. Mature Coping Among Life-Sentenced Inmates: An Exploratory Study of Adjustment Dynamics. Corrections Compendium, v. 30, n. 6, p. 8-9, 36, 38, 2005.

JOHNSON, Robert; MCGUNIGALL-SMITH, Sandra. Life Without Parole, America's Other Death Penalty: Notes on Life Under Sentence of Death by Incarceration. The Prison Journal v. 88, n. 2, p. 328-346, 2008.

KAEMINGK, Denny. Volunteer Handbook. Sioux Falls: South Dakota Department of Corrections, 2018.

KUSHNER, Rachel. Is Prison Necessary? Ruth Wilson Gilmore Might Change Your Mind. New York Times Magazine, United States, n. 17 abr. 2019. Disponível em <https://www.nytimes.com/2019/04/17/magazine/prison-abolition-ruth-wilsongilmore.html>. Acesso em: 14 out. 2020.

LUCAS, Ashley. Traveling Inside: The walls of a prison close off the world; a stage can open it. Plough Quarterly Magazine, n. 25, 12 de agosto de 2020. Disponível em<https://www.plough.com/en/topics/justice/social-justice/criminaljustice/traveling-inside>. Acesso em: 14 out. 2020.

MARGOLIASH, Daniel. Song learning and sleep. Nature neuroscience, v. 8, n. 5, p. 546-548, 2005.

MATTINGLY, Kate. Comunicação pessoal, 13 de outubro de 2020, Utah,United States.

MCKEGNEY, Sam. Into the Full Grace of the Blood in Men: An Introduction. In Masculindians: Conversations about Indigenous Manhood, ed. Sam McKegney. East Lansing, MI: Michigan State University Press, 2014, p. 1. 
MERRIAM-WEBSTER. Drift. Merriam-Webster Dictionary Online,United States, n. 2020. Disponível em <https://www.merriam-webster.com/dictionary/drift>. Acesso em: 14 out. 2020.

MITHLO, Nancy Marie. No word for art in our language? Old questions, new paradigms. Wicazo Sa Review, v. 27, n. 1, p. 111-126, 2012.

O’REILLY, Kelley; ECKERT, Jim. Building Relationships From the Outside In: A Case Study of Falken Tire's Drift Toward Success. Journal of Relationship Marketing v. 13, n. 3, p. 243-262, 2014.

PELTIER, Leonard. Prison Writings: My Life Is My Sun Dance. ed. Harvey Arden. New York City: St. Martin's Press, 1999.

POSTHUMUS, David. All My Relatives: Exploring Lakota Ontology, Belief, and Ritual. Lincoln: University of Nebraska Press, 2018.

RODRIGUEZ, Dylan. Forced Passages: Imprisoned Radical Intellectuals and the U.S. Prison Regime. Minneapolis: University of Minnesota Press, 2006.

ROSADO, Alexander. Ligação telefônica Tria Blu Wakpa. 24 de setembro de 2020, South Dakota, United States.

ROSS, Luana. Inventing the Savage: The Social Construction of Native American Criminality. Austin: University of Texas Press, 1998.

SANCHEZ, Tony R. "Dangerous Indians" Evaluating the Depiction of Native Americans in Selected Trade Books. Urban Education v. 36, n. 3, p. 400-425, 2001.

SIMPSON, Leanne; WINDER, Tanaya. Falling Into Decolonial Love: An Interview with Leanne Simpson, Author of Islands of Decolonial Love: Stories and Songs. As Us: A Space for Women of the World, v. 4, 2014.

SMITH, Linda Tuhiwai. Decolonizing Methodologies: Research and Indigenous Peoples. London: Zed Books, 1999.

SOTO, Claradina; HANDBOY, Toni; SUPRANOVICH, Ruth; WEISS, Eugenia L. The Women of the Cheyenne. In: Women's Journey to Empowerment in the 21st Century: A Transnational Feminist Analysis of Women's Lives in Modern Times. ed. Kristen Zaleski, Annalisa Enrile, Xiying Wang, and Eugenia L. Weiss. Oxford: Oxford University Press, 2019, p. 87-104.

SOUTH DAKOTA DEPARTMENT OF CORRECTIONS. Programs: Paroled Pups. South Dakota Department of Corrections Online, 2020. Disponivel em <https://doc.sd.gov/about/programs/paroled_pups.aspx>. Acesso em: 14 out. 2020. 
TERRY, Charles M. The function of humor for prison inmates. Journal of Contemporary Criminal Justice v. 13, n. 1, p. 23-40, 1997.

$\mathrm{TOCH}$, Hans. Studying and reducing stress. In: The pains of imprisonment, eds. R. Johnson and H. Toch. Washington DC: American Psychological Association, 1998, p. $22-44$.

WALMSLEY, Roy. World Prison Population List. World Prison Brief. Institute for Criminal Policy Research, 2016. Disponivel em <https://www.prisonstudies.org/news/more-1035-million-people-are-prisonaround-world-new-report-shows>. Acesso em: 14 out. 2020.

WHIRLWIND SOLDIER, Lydia. Wancantognaka: the continuing Lakota custom of generosity. Tribal College v. 7, n. 3, p. 10, 1996.

WHITE HAT, Albert. Reading and Writing the Lakota Language. Salt Lake City: University of Utah Press, 1999.

WILBUR, Matika; KEENE, Adrienne. Healing The Land IS Healing Ourselves. All My Relations Podcast, 26 de maio de 2020. Disponível em <https://www.allmyrelationspodcast.com/podcast/episode/4bb3fff4/healing-theland-is-healing-ourselves>. Acesso em: 14 out. 2020.

WILSON, Sean. Research Is Ceremony: Indigenous Research Methods. Nova Scotia: Fernwood Publishing Co. Ltd., 2008.

ZAMBLE, Edward. Behavior and adaptation in long-term prison inmates: Descriptive longitudinal results. Criminal Justice and Behavior, v. 19, n. 4, p. 409-425, 1992.

Recebido em: 12/12/2020

Aprovado em: 12/12/2020 